\title{
CUKRINIS DIABETAS IR SARS-COV-2 INFEKCIJA
}

\author{
Kamilè Antanavičiūtè, Rūta Šarkūnaitė \\ Lietuvos sveikatos moksly universiteto Kauno klinikos
}

Raktažodžiai: SARS-CoV-2, Covid-19, cukrinis diabetas, paplitimas, baigtys.

\begin{abstract}
Santrauka
Tyrimo tikslas - išanalizuoti ir susisteminti įrodymais pagrịstus duomenis, pateiktus 2020 - 2021 metais paskelbtuose moksliniuose straipsniuose apie bendrą cukrinio diabeto $(\mathrm{CD})$ ir Covid ligos patogenezę, $\mathrm{CD}$ dažni sergančiujų Covid liga populiacijoje bei CD ịtaką šios ligos baigčiai. Išanalizuota 20 straipsnių. Tyrimo rezultatai. Pagrindinis patogenezinis mechanizmas, lemiantis sunkią Covid eigą CD populiacijoje, susijęs su hiperglikemijos ir citokinų hipersekrecijos sukelta endotelio pažaida bei jos sukelta hiperkoaguliacine būkle. Nustatytas CD dažnis varijuoja tarp 7,4 ir 33 proc. Covid liga sergančių pacientų bei CD statistiškai reikšmingai dažniau buvo nustatytas pacientams, kurie sirgo sunkesne Covid ligos forma: buvo dirbtinès plaučiu ventiliacijos (DPV) ar gydymo intensyviosios terapijos skyriuje poreikis.
\end{abstract}

\section{Ivadas}

Pandemija, kardinaliai pakeitusi pasaulio gyvenimo būdą, prasidèjo 2019 m. gruodžio 31 d., kai pirmą kartą buvo užfiksuotas nežinomos etiologijos komplikuotos pneumonijos atvejis. Neilgai trukus buvo nustatytas ir sukèlèjas - sunkaus ūminio kvépavimo sindromo koronavirusas, geriau žinomas kaip SARS-CoV-2 (angl. severe acute respiratory syndrome coronavirus 2). Šis atvejis užfiksuotas Wuhan mieste, Kinijoje. Nepraejus 3 ménesiams, Pasaulio sveikatos organizacija $2020 \mathrm{~m}$. kovo $11 \mathrm{~d}$. SARS-CoV-2 infekciją paskelbè pasauline pandemija [1]. Didejjant susirgimų ir mirčių nuo Covid ligos skaičiui, tyrejjams iš viso pasaulio kilo klausimas, nuo ko priklauso teigiama ir neigiama šios ligos baigtis. Nagrinejjant sergančiųu populiacijas buvo pastebėta, jog didžiulę ju dali sudaro sergantieji cukriniu diabetu (CD) ir galimai ši liga prisideda prie blogesnès Covid ligos baigties [2].

Tyrimo tikslas - išanalizuoti ir susisteminti ịrodymais pagristus duomenis, pateiktus 2020-2021 metais paskelbtuose moksliniuose straipsniuose, apie bendrą CD ir Covid ligos patogenezę, CD dažnị sergančiujų Covid liga populiacijoje bei CD įtaką šios ligos baigtims.

\section{Tyrimo medžiaga ir metodai}

Buvo atlikta mokslinès literatūros bei dokumentų apžvalga ir analizė PubMed, the Web of Science, UpToDate internetinèse duomenų bazėse, naudojant raktinius žodžius SARS-CoV-2, Covid-19, Covid disease, Diabetes, Prevalence, Outcomes. Iš gautų rezultatų buvo atrinkta 20 viso teksto straipsnių anglų kalba, paskelbtų 2020-2021 metais, kurie atitiko pasirinktus raktinius žodžius bei kuriuose buvo nagrinèta benda CD ir Covid ligos patogenezè, CD dažnis Covid liga sergančiujų populiacijoje ir pateikti su CD susijusios baigties rezultatai.

\section{Tyrimo rezultatai}

SARS-CoV-2 pavojus sergančiųjų CD populiacijai. Remiantis Tarptautinès diabeto federacijos apibrež̌timi, cukrinis diabetas yra lètinè liga, sukelianti mikrovaskulines ir makrovaskulines komplikacijas. Ši liga skirstoma $\mathfrak{i}$ nuo insulino priklausomą diabetą, išsivysčiusị dèl visiško insulino trūkumo, kai kasos Langerhanso ląstelès nustoja skirti insuliną (1 tipo CD) ir nuo insulino nepriklausomą, išsivysčiusị dèl padidejusio ląstelių atsparumo insulinui (2 tipo CD) [3]. Yra žinoma, jog sergant diabetu, neigiamai paveikiamas imunitetas: susilpnèja neutrofilų, makrofagų ir monocitų fagocitozé, neutrofilų chemotaksis ir baktericidinis aktyvumas, sukeliantis ląstelinio imuniteto susilpnejjimą [4]. Dèl blogos CD kontrolès ilgalaikè hiperglikemija suintensyvina glikozilinimo produktų ir uždegimą skatinančių citokinų sintezę, kurie sukelia oksidacinį stresą ląstelèse ir didina infekcijų riziką [5]. I organizmą patekus SARSCoV-2, sukeliama nauja imuninio atsako banga: T limfocitai pagalbininkai produkuoja gama interferoną, kuris sukelia dar didesnę imuninių ląstelių audrą organizme. Sergančiujų CD ląstelèse jau susidaręs oksidacinis stresas, todèl papildomas viruso sukeltas imuninis atsakas gali lemti daugini organų pažeidimą ir blogą Covid ligos baigtị [6]. 
Kitas patogenezinis mechanizmas, sukeliantis sunkią Covid ligos eigą CD sergančiųjų populiacijoje, susijęs su angiotenziną konvertuojančio fermento II (AKF II) ekspresija. Šis fermentas randamas daugelyje organų: plaučių, kasos, inkstų audiniuose, kraujagysles ir virškinimo traktą sudarančiame endotelyje. AKF II atsakingas už angiotenzino II virtimą angiotenzinu I, kuris dalyvauja uždegimą slopinančiose reakcijose. Yra žinoma, jog SARS-CoV-2 panaudoja AKF II, esantị ląstelių paviršiuje, kad patektų ị ląstelių vidų ir jas sunaikintų $[7,8]$. Tai, jog AKF II molekulès randamos ir kasos ląstelių paviršiuje, kelia didžiulį pavojų diabetu sergantiems pacientams: ardant insuliną išskiriančias ląsteles, didèja hiperglikemijos rizika, galinti sukelti ūmią, gyvybei pavojingą būklę diabetinę ketoacidozę ar padidinti kitų infekcijų riziką, pavyzdžiui, SARS-CoV-2 sukeltą pneumoniją komplikuoti bakterine pneumonija $[9,10]$.

CD dažnis sergančiųjų Covid liga populiacijoje. Nagrinejjant pastaraisiais metais paskelbtus informacijos šaltinius, stebèta, jog sergančiujų CD dažnis SARS-CoV-2 infekuotųu populiacijoje stipriai varijuoja. Kinijoje atliktose metaanalizèse dalyvavo 46248 ir 76993 Covid-19 pacientai. Diabetas nustatytas 8,6 ir 7,9 proc. pacientų $[11,12]$. Kinijos tyrejas W. Guan su kolegomis atliko tyrimą, kuriame dalyvavo 1099 Covid-19 pacientai ir nustatytas CD dažnis tiriamujų populiacijoje buvo 7,4 procento. Šio tyrimo metu nustatyta, jog CD statistiškai reikšmingai dažniau buvo diagnozuotas pacientams, kurie sirgo sunkesne Covid liga. Lyginant su lengvesne ligos forma sirgusiais pacientais, jiems buvo dirbtinès plaučių ventiliacijos (DPV) ar gydymo intensyviosios terapijos skyriuje poreikis [13]. Ta pati mokslininkų grupe atliko dar vieną tyrimą, kuriame dalyvavo 1590 dalyvių. Tarp jų CD nustatytas 8,2 proc. dalyvavusiujų ir CD buvo nustatytas statistiškai dažniau sunkia ligos forma sergantiems $(34,6$ ir 14,3 proc.) [14]. Rasta tyrimų, kurie teigia, jog nėra pagrindo manyti, kad sergantys CD SARS-CoV-2 virusu užsikrečia lengviau. Kitoje Kinijoje atliktoje metaanalizèje, kurioje aptarta 2108 sergančiujų Covid liga pacientų informacija, nustatyta, jog CD dažnis šioje populiacijoje buvo 10,3 proc, kai bendroje Kinijos populiacijoje 2013 metas sergančiuju CD dažnis buvo beveik toks pat $-10,9$ procento $[15,16]$.

CD ịtaka Covid ligos baigtims. Yra žinoma, jog gretutinès ligos sunkina ịvairių infekcinių ligų eigą, tačiau mažai žinoma apie CD poveikị Covid ligos eigai ir baigtims. Ar galima CD laikyti Covid ligos blogos baigties prognoztiniu veiksniu? Tyrejjas W. Guo su kolegomis pastebejjo, jog CD ir Covid liga sergančiųų kraujyje buvo nustatytas statistiškai reikšmingai didesnis IL-6, CRB, feritino, D-dimerų kiekis bei hiperkoaguliacija, lyginant su pacientais, sergančiais tik Covid liga. Galima manyti, jog tiek $\mathrm{CD}$, tiek padidejęs rezistentiškumas insulinui tiesiogiai sukelia endotelio disfunkciją ir padidina trombocitų agregaciją, todèl šis hiperkoaguliacinis poveikis dar labiau didina trombozių ir dauginio organu pažeidimo riziką Covid sergančiujų populiacijoje [17,18]. T. Guo komandos tyrimų rezultatai patvirtina W. Guan tyrimo rezultatus. T. Guo pastebejo, jog nors ir CD dažnis Covid pacientų populiacijoje buvo tik 7,4 proc, tačiau tarp komplikuota ligos forma sergančiųų CD pasireiškè net 4,4 karto dažniau, nei esant nekomplikuotai ligos eigai [19]. L. Shang su kolegomis atliktoje sisteminėje literatūros apžvalgoje ir metaanalizejje buvo nagrinètos 76 studijos, kuriose iš viso dalyvavo 31067 tiriamieji. Šios analizès metu nustatyta, jog CD sergantiems Covid-19 pacientams dažniau pasireiškẻ sunki ligos forma, lyginant su nesergančiais CD $(21,4 \%$ vs. $10,6 \%, p<0,01)$. CD populiacijoje nustatytas daugiau nei dvigubai didesnis mirtingumas nuo Covid ligos, lyginant su nesergančiais CD $(28,5 \%$ vs. $13,3 \%, p<0,01)$. Šio tyrimo metu nustatytas CD sergantiems komplikuotos eigos rizikos ŠS $[95 \%$ PI] ( $\breve{S} S=2,3895 \%[2,05-2,78], \mathrm{p}<0,001)$ bei mirtingumo tikimybès ŠS, lyginant su nesergančiais CD ( $\breve{S} S=2,2195 \%[1,83-2,66], p<0,001)$ buvo statistiškai reikšmingai didesnis [20]. A. Caballero su bendraautoriais (2020) aprašè tyrimą, kuriame buvo nagrinejjama Covid-19 ligos eiga ir baigtis 7 šalyse: JAV, Italijoje, Indijoje, Kolumbijoje, JAE, Kinijoje bei Kamerūne [21].

Remiantis 72314 Covid ligos pacientų duomenimis iš Kinijos, mirties rizika sergant CD 2,12 karto, sunki ligos eiga buvo 2,4 karto, o ūminio respiracinio distreso sindromas pasireiškè net 4,6 karto dažniau lyginant su pacientais, nesergančiais CD [22]. Pasaulio sveikatos organizacija pateikè duomenų, jog CD dažnis Europoje siekia net 33 proc. sergančiųjų Covid liga [23]. Ivvertinę ịvairių šalių duomenis, tyrējai bendrai sutare, jog ši pandemija yra didžiulis iššūkis $\mathrm{CD}$ bendruomenei, kuris privertė medicinos personalą peržiūrèti ir iš esmès keisti sergančiǔjų priežiūros strategijas.

Nors didelè dalis nagrinètų šaltinių patvirtina, jog CD yra rizikos veiksnys Covid ligos progresavimui ir lemia blogesnę ligos prognozę, tačiau dauguma tyrèjų susidūrè su problemomis, galimai iškreipiančiomis rezultatus. Viena iš jų - tiriamujų amžius: daugumoje tyrimų CD grupès pacientų amžius buvo didesnis, nei nesergančių CD. Nėra žinoma, ar sirgusiujų CD ligos kontrole buvo pakankama. Be to, pasirinkto gydymo ypatumai galëjo iškreipti atliktų tyrimų rezultatus [24].

\section{Išvados}

1. Pagrindiniai patogeneziniai mechanizmai, lemiantys didesnį pavojų CD populiacijai sergant Covid liga, yra tokie: viruso sukeltas beta ląstelių pažeidimas didina hiperglikemiją, kuri sukelia endotelio pažeidimus, oksidacinị stresą ląstelèse ir padidina citokinų išskyrimą. Šie veiksniai lemia 
hiperkoaguliacinę būklę, kuri didina trombozių ir dauginio organų pažeidimo riziką.

2. Remiantis nagrinèta literatūra, $C D$ dažnis sergančiųų populiacijoje varijuoja tarp 7,4 ir 33 proc. Covid liga sergančių pacientų, tačiau kol kas nėra bendros nuomonès, kad CD sergantieji yra imlesni SARS-CoV-2 virusui.

3. Visose nagrinètose publikacijose $\mathrm{CD}$ statistiškai reikšmingai dažniau buvo nustatytas pacientams, kurie sirgo sunkesne Covid ligos forma: buvo dirbtinès plaučiu ventiliacijos ar gydymo intensyviosios terapijos skyriuje poreikis.

\section{Literatūra}

1. Coronavirus COVID-19 global cases by the Center for Systems Science and Engineering (CSSE) at Johns Hopkins University. 2020.

https://systems.jhu.edu/research/public-health/ncov/.

2. Li B, Yang J, Zhao F, Zhi L, Wang X, Liu L, et al. Prevalence and impact of cardiovascular metabolic diseases on COVID-19 in China. Clin Res Cardiol 2020; 109(5):531-538. https://doi.org/10.1007/s00392-020-01626-9

3. Tarptautinè diabeto federacija. https:/www.idf.org/aboutdiabetes/what-is-diabetes.html

4. Wu H, Lau ESH, Ma RCW, Kong APS, Wild SH, Goggins W, et al. Secular trends in all-cause and cause-specific mortality rates in people with diabetes in Hong Kong, 2001-2016: a retrospective cohort study. Diabetologia 2020; 63:757-766. https://doi.org/10.1007/s00125-019-05074-7

5. Knapp S. Diabetes and infection: is there a link? - a mini-review. Gerontology 2013;59(2):99-104. https://doi.org/10.1159/000345107

6. Singh AK, Gupta R, Ghosh A, Misra A. Diabetes in COVID-19: prevalence, pathophysiology, prognosis and practical considerations. Diabetes Metab Syndr Clin Res Rev 2020;14:303-10. https://doi.org/10.1016/j.dsx.2020.04.004

7. Lu R, Zhao X, Li J, Niu P, Yang B, Wu H et al. Genomic characterisation and epidemiology of 2019 novel coronavirus: implications for virus origins and receptor binding. Lancet 2020;395(10024):565-574. https://doi.org/10.1016/S0140-6736(20)30251-8

8. Hartmann-Boyce J, Morris E, Goyder C, Kinton J, Perring J, Nunan D et al. Diabetes and COVID-19: risks, management, and learnings from other national disasters. Diabetes Care 2020;43(8):1695-1703.

https://doi.org/10.2337/dc20-1192

9. Yang Jin-Kui, Lin Shan-Shan, Ji Xiu-Juan, Guo Li-Min. Binding of SARS coronavirus to its receptor damages islets and causes acute diabetes. Acta Diabetol 2010;47(3):193-9.

https://doi.org/10.1007/s00592-009-0109-4

10. Liu F, Long X, Zhang B, Zhang W, Chen X, Zhang Z. ACE2 expression in pancreas may cause pancreatic damage after SARS-CoV-2 infection. Clin Gastroenterol Hepatol 2020;18:2128-2130.e2.

https://doi.org/10.1016/j.cgh.2020.04.040

11. Li B, Yang J, Zhao F, Zhi L, et al. Prevalence and impact of cardiovascular metabolic diseases on COVID-19 in China. Clin Res Cardiol 2020;109(5):531-538. https://doi.org/10.1007/s00392-020-01626-9

12. Yang J, Zheng Y, Gou X, et al. Prevalence of comorbidities in the novel Wuhan coronavirus (COVID-19) infection: a systematic review and meta-analysis. Int J Infect Dis 2020;94:91-95. https://doi.org/10.1016/j.ijid.2020.03.017

13. Guan WJ, Ni ZY, Hu Y, et al. Clinical characteristics of coronavirus disease 2019 in China. N Engl J Med 2020;382(18):17081720.

https://doi.org/10.1056/NEJMoa2002032

14. Guan WJ, Liang WH, Zhao Y, et al. China medical treatment expert group for Covid-19. Comorbidity and its impact on 1590 patients with Covid-19 in China: a nationwide analysis. Eur Respir J 2020;55(5):2000547.

https://doi.org/10.1183/13993003.00547-2020

15. Guo W, Li M, Dong Y, et al. Diabetes is a risk factor for the progression and prognosis of COVID-19. Diabetes Metab Res Rev 2020;e3319.

https://doi.org/10.1002/dmrr.3319

16. Fadini G, Morieri M, Longato E, Avogaro A. Prevalence and impact of diabetes among people infected with SARS-CoV-2. J End Invest 2020;43(6):867-869. https://doi.org/10.1007/s40618-020-01236-2

17. Wang L, Gao P, Zhang M, Huang Z, Zhang D, Deng Q et al. Prevalence and ethnic pattern of diabetes and prediabetes in China in 2013. JAMA 2017;317(24):2515. https://doi.org/10.1001/jama.2017.7596

18. Dunn E, Grant P. Type 2 diabetes: an atherothrombotic syndrome. Current Molecular Medicine 2005;5(3):323-332. https://doi.org/10.2174/1566524053766059

19. Guo T, Fan Y, Chen M, Wu X, Zhang L, He T, Wang H, Wan J, Wang X, Lu Z. Cardiovascular implications of fatal outcomes of patients with coronavirus disease 2019 (COVID-19). JAMA Cardiol 2020;e201017. https://doi.org/10.1001/jamacardio.2020.1017

20. Shang L, Shao M, Guo Q, Shi J, Zhao Y, Xiaokereti J et al. Diabetes mellitus is associated with severe infection and mortality in patients with COVID-19: a systematic review and meta-analysis. Arch Med Res 2020;51(7):700-709.

https://doi.org/10.1016/j.arcmed.2020.07.005

21. Caballero AE, Ceriello A, Misra A, Aschner P, McDonnell ME, Hassanein M, Ji L, Mbanya JC, Fonseca VA. COVID-19 in people living with diabetes: An international consensus. J Diabetes Complications 2020;34(9):107671.

22. Yang J, Zheng Y, Gou X, et al. Prevalence of comorbidities and its effects in patients infected with SARS-CoV-2: a systematic review and meta-analysis. Int J Infect Dis 2020;94:91-5. 
https://doi.org/10.1016/j.ijid.2020.03.017

23. World Health Organisation.Covid-19 week https://www.euro. who.int/en/healthtopics/ health-emergencies/coronavirus-covid-19/weekly-surveillance-report

24. Tadic M, Cuspidi C, Sala C. COVID-19 and diabetes: is there enough evidence? J Clin Hypertension 2020;22(6):943-948.

https://doi.org/10.1111/jch.13912

DIABETES AND COVID - SARS - 2 INFECTION. WHAT WE HAVE LEARNED DURING THE FIRST YEAR OF PANDEMIA?

\section{K. Antanavičiūtè, R. Šarkūnaitè}

Keywords: SARS - CoV-2, Covid - 19, Covid disease, Diabetes, Prevalence, Outcomes.

\section{Summary}

The aim of this study was to analyse and summarise evidence based data about the common Diabetes mellitus (DM) and Covid disease pathogenesis, DM prevalence in Covid - 19 patients po- pulation and DM impact for this disease outcomes. In this review we presented summarised data from 20 studies, published in 2020 - 2021. According to our findings the main pathogenetic pathway between DM and Covid disease is related with constant hyperglycaemia and cytokines hypersecretion, which lead to endothelial dysfunction and hypercoagulation. DM prevalence in Covid patients was found between 7,4\% and 33\% and was found statistically significant more prevalent in severe Covid patients: patients with necessary mechanical ventilation or admission to an intensive care unit.

Correspondence to: kamile.antanaviciute@gmail.com 